\title{
Overstory Longleaf Pines and Hardwoods Create Diverse Patterns of Energy Release and Fire Effects During Prescribed Fire
}

\author{
Andrew W. Whelan ${ }^{1 *}$, Seth W. Bigelow ${ }^{1}$ and Joseph J. O'Brien ${ }^{2}$ \\ 1 The Jones Center at Ichauway, Newton, GA, United States, ${ }^{2}$ Southern Research Station, United States Forest Service \\ (USDA), Athens, GA, United States
}

OPEN ACCESS

Edited by:

Kajar Köster,

University of Helsinki, Finland

Reviewed by:

Eliana Lima da Fonseca,

Federal University of Rio Grande do

Sul, Brazil

Andrew Thomas Hudak, Rocky Mountain Research Station, United States Forest Service (USDA), United States

*Correspondence: Andrew W. Whelan andy.whelan@jonesctr.org

Specialty section: This article was submitted to Fire and Forests,

a section of the journal Frontiers in Forests and Global

Change

Received: 25 January 2021 Accepted: 16 March 2021 Published: 12 April 2021

Citation:

Whelan AW, Bigelow SW and O'Brien JJ (2021) Overstory Longleaf Pines and Hardwoods Create Diverse Patterns of Energy Release and Fire Effects During Prescribed Fire.

Front. For. Glob. Change 4:658491. doi: 10.3389/ffgc.2021.658491
Litter from pine trees in open woodlands is an important fuel for surface fires, but litter from hardwood species may quell fire behavior. Lower intensity fires favor hardwood over longleaf pine regeneration, and while overstory hardwoods are important sources of food and shelter for many wildlife species, too many could result in canopy closure and a loss of ground layer diversity. Although some researchers have found synergies in fire effects when leaves of different species are combined, field tests of effects of tree guild diversity on fire behavior are lacking from the literature. We used neighborhood modeling to understand how diverse overstory trees in longleaf pine forests affect fire radiative energy density (FRED), and to determine the effect on top-kill of shrub-form hardwood trees. We measured the effects of three guilds of overstory trees (longleaf pine, upland oaks, and mesic oaks) on FRED, and related FRED to post-fire damage in four guilds of understory hardwoods (sandhill oaks, upland oaks, mesic oaks, and fleshy-fruited hardwoods). We found that FRED increased 33-56\% near overstory longleaf pine but decreased 23-37\% near overstory mesic oaks. Additive models of FRED performed well and no synergies or antagonisms were present. Seventy percent of stems of understory hardwoods survived fire with energy release typical of dormant-season fires in canopy gaps and near overstory mesic oaks. We also found that among understory trees $>2 \mathrm{~m}$ tall, upland and sandhill oaks were more likely than mesic oaks or fleshyfruited hardwoods to avoid top-kill. We conclude that neighborhood models provide a method to predict longleaf pine forest structure and composition that allows for the ecological benefits of overstory hardwoods while maintaining ground-layer diversity. To maintain hardwood control, fire practitioners may need to select fire weather conditions to increase fire behavior especially during dormant-season burns.

Keywords: controlled burn, neighborhood methods, maximum likelihood, fire radiative energy density, longleaf pine, non-additive effects

\section{INTRODUCTION}

Frequent fire maintains the open canopy structure of longleaf pine (Pinus palustris Mill.) woodlands in part by preventing hardwood trees, which are often abundant in the understory, from growing to fire-resistant size (Provencher et al., 2001; Whelan et al., 2018). Reduced fire frequency and intensity may reduce aboveground stem mortality (top-kill) of understory hardwood trees, resulting in 
development of a dense hardwood-dominated midstory (Glitzenstein et al., 1995; Hiers et al., 2007). Dense midstory or overstory tree canopies reduce light availability at the ground, and result in a loss of floristic diversity, which can be exceptionally high in frequently burned longleaf pine woodlands (Kirkman et al., 2001). Overstory trees provide fuel for fire, and the burning characteristics of their litter vary by species (Fonda, 2001; Kane et al., 2008; Kreye et al., 2018). Nevertheless, few studies link the spatial arrangement of overstory trees with energy release during fire (O'Brien et al., 2008, 2016).

Trees have traits that both influence and are influenced by fire regimes (Cavender-Bares et al., 2004; Varner et al., 2016), mediated primarily by leaf litter deposition. Overstory trees may create fire regimes to which they are well-adapted by depositing litter that alters fire behavior (Mitchell et al., 2009). Flame residence time increases with proximity to longleaf pine (Bigelow and Whelan, 2019), and longleaf pine needles are high in terpenes, which increase burn time (Ormeño et al., 2009). Leaves of hardwood trees common to longleaf pine woodlands burn with varying intensity (Kane et al., 2008). Hardwoods adapted to drier soils and high frequency fire (hereafter upland hardwoods) often have large leaves that burn more intensely than leaves of hardwoods adapted to mesic soils and lower fire frequency (hereafter mesic hardwoods). The flammability of leaves of some xeric hardwoods has been observed to be equivalent in many measures to those of longleaf pine (Kane et al., 2008). Larger leaves tend to curl when they dry creating a well-aerated fuel bed that burns, while smaller leaves tend to create a moist, dense fuelbed which restricts air circulation and impedes the flow of oxygen during fire (Varner et al., 2016). Differences in canopy-derived surface fuels may lead to higher energy release near longleaf pines and upland hardwoods, and lower energy release near mesic hardwoods (Williamson and Black, 1981). The resulting fire effects may tend to create positive feedbacks whereby trees create conditions that favor their own species (Gagnon et al., 2010).

Non-additivity in the effects of mixing fuels on fire metrics occurs when fire properties in mixture deviate from those expected based on component species when burnt alone. Over the past decade a number of researchers have tested for nonadditive effects of multi-species fuel mixtures on fire behavior metrics. There have been many findings of non-additive effects on metrics such as spread rate, flame height, and flame duration (de Magalhães and Schwilk, 2012; Blauw et al., 2015; Della Rocca et al., 2018; Zhao et al., 2019; Gormley et al., 2020), but investigations/findings of non-additivity with regard to fundamental physical factors that cause fire effects (e.g., heat energy release) have been fewer (de Magalhães and Schwilk, 2012; Della Rocca et al., 2018). Non-additivity can be important in forest ecosystem science because when it occurs, area-based rates of an ecosystem process (e.g., nutrient cycling, energy release from fire) will not simply equal the mean value predicted from all species present but will be influenced by spatial arrangement of overlapping circles of influence of neighboring trees (Canham and Uriarte, 2006; Bigelow and Canham, 2017). Individual longleaf pine trees' effects on prescribed fire air temperatures and residence time have been modeled as circles of influence (Bigelow and Whelan, 2019). Nevertheless, the effect of co-occurring hardwoods (e.g., suite of oaks) has not been modeled, and the interaction with longleaf pine is of interest because of the importance of prescribed fire for hardwood control via top-kill.

Prescribed fire science has progressed in recent decades so that the use of instruments such as thermocouples for measuring fire properties is commonplace (Loudermilk et al., 2017). Nevertheless, the use of air temperature as a measurement of fire behavior and a predictor of fire effects has been criticized as limited, because heat energy rather than temperature produces fire effects (Johnson and Miyanishi, 2001). Fire radiant energy density (FRED) measurement cannot be carried out with readily available commercial sensors, but measurements with custom made sensors are increasingly common (Kremens et al., 2012; Ottmar and Restaino, 2014; Dickinson and Kremens, 2015). Radiant energy release during fire is related to both fuel consumption and to fire effects on surrounding vegetation (woody stems).

Although the contribution of ground-layer fuels to fire behavior is well understood, few have linked fire behavior with the composition and spacing of overstory trees (Williamson and Black, 1981; O’Brien et al., 2008). Neighborhood theory, in which fine-scale spatial interactions regulate the demography of component tree species (Pacala et al., 1996), is a developing paradigm for understanding forest dynamics but has been littleused for studies of fire (Bigelow and Whelan, 2019). Analysis of how overstory trees affect any process on the ground requires a functional form describing a tree's influence on that process (Canham and Uriarte, 2006). The functional form of a tree's influence usually reflects both the effect of tree size and how that effect changes with distance. Neighborhood methods commonly use mapped stands to estimate parameters based on size and distance of trees within a specified radius at points where a process has been measured: the best fit of model to data is provided by the most likely parameters (Burnham and Anderson, 2002). Neighborhood analysis has been used in studies of overstory tree effects on nutrient cycling (Bigelow and Canham, 2015), seed dispersal (Ribbens et al., 1994), and leaf dispersal (Ferrari and Sugita, 1996); fire behavior represents a novel application (Bigelow and Whelan, 2019).

Differences in fire behavior due to overstory tree neighborhood could result in competitive advantages for some hardwood species (Thaxton and Platt, 2006). Hardwood stems are killed during prescribed fire if the cambium is heated to the point of cell death $\left(\mathrm{ca} .60^{\circ} \mathrm{C}\right.$ ), and resistance to cambial damage has been linked to bark thickness (Bova and Dickinson, 2005). Hardwoods adapted to drier conditions and higher fire frequency tend to have thicker bark and are more fire resistant than hardwoods adapted to more mesic soils and lower fire frequency (Hammond et al., 2015). Overstory trees may create fire regimes to which they are better adapted by depositing litter that alters fire frequency and behavior (Mitchell et al., 2009). Neighborhood analysis provides the opportunity to infer fire behavior from the spatial distribution and composition of overstory trees.

We wished to know how overstory trees affect fire behavior, and how changes in fire behavior affect understory hardwoods. We address the following hypotheses: (1) energy release will 
increase with proximity to longleaf pine and upland oak species and will decrease with proximity to mesic oak species, (2) intermingling of different tree guilds will have non-additive effects on energy release, and (3) shrub-form hardwoods of upland and xeric habitats will be more resistant to top-kill than hardwoods of mesic habitats at any level of energy release during prescribed fire. A better understanding of these uncertainties will provide a means to predict fire behavior and understory hardwood control in proximity to overstory trees in longleaf pine woodlands.

\section{MATERIALS AND METHODS}

\section{Study Site}

The study was done at The Jones Center at Ichauway in Baker County, GA, United States $\left(31^{\circ} 14^{\prime} 00 \mathrm{~N}, 84^{\circ} 28^{\prime} 00 \mathrm{~W}\right.$, mean elevation $50 \mathrm{~m}$ ) within the Gulf Coastal Plain physiographic province. The study site is within the Dougherty Plain physiographic district, which is a karst landscape characterized by Ocala Limestone overlain by weakly dissected alluvial deposits (Hodler and Schretter, 1986). Most of the longleaf pine woodland at the study site occurs on well-drained loamy sand over sandy loam soils classified as Psammentic Kandiudults or Grossarenic Kandiudults (Goebel et al., 1997). Typical soil water holding capacity in the upper $300 \mathrm{~cm}$ of soil is $28 \mathrm{~cm}$ per meter of soil. The regional climate is humid subtropical. The site receives an average of $1360 \mathrm{~mm}$ of precipitation annually, and mean temperatures range from 3 to $18^{\circ} \mathrm{C}$ in the winter and from 20 to $33^{\circ} \mathrm{C}$ in the summer (NCEI, 2010).

The study site is dominated by open canopy second-growth longleaf pine woodland. Overstory trees were established early in the twentieth century following the cessation of commercial forest activity (Pederson et al., 2008). Since that time, the site has been managed for bobwhite quail (Colinus virginianus virginianus $\mathrm{L}$.) with prescribed fire on a 2-3 year interval as the primary land management tool. Periodic individual-tree selection harvests have been conducted to improve habitat and forest health (McIntyre et al., 2008). Mean basal area in upland areas is $13 \mathrm{~m}^{2} \mathrm{ha}^{-1}$ (Holland et al., 2019). Relative proportion of basal area is $75 \%$ longleaf pine, $12 \%$ upland oak (e.g., southern red oak and post oak; Table 1), and 9\% mesic oak (e.g., live oak, laurel oak, and water oak). Hardwood trees $<2 \mathrm{~m}$ in height are common in the understory at an estimated density of 1000$2000 \mathrm{ha}^{-1}$ (Whelan et al., 2018). Legacy of soil disturbance, primarily subsistence agriculture, has produced variable ground cover; wiregrass (Aristida stricta Michx.) with a variety of warm season bunchgrasses and forbs dominates on soils that did not have a history of soil disturbance, and wiregrass is reduced or absent on soils that have a history of disturbance. Typical ground cover standing crop one growing season after dormant-season prescribed fire is $0.1 \mathrm{~kg} \mathrm{~m}^{-2}$ (Kirkman et al., 2016).

\section{Experimental Design and Measurement of Fire Temperature}

We collected data on temperature, radiant heat, forest structure, and fuels during fires in three successive years (2017-2019;
TABLE 1 | Tree species common to longleaf pine woodlands in SW Georgia, United States.

\begin{tabular}{lcc}
\hline Common name & Latin name & Guild \\
\hline $\begin{array}{lcc}\text { Longleaf pine } & \text { Pinus palustris Mill. } & \text { conifer } \\
\text { Southern red oak } & \text { Quercus falcata Michx. } & \text { upland oak } \\
\text { Post oak } & \text { Quercus stellata Wangenh. } & \text { upland oak } \\
\text { Sand post oak } & \text { Quercus margaretta Ashe. } & \text { upland oak } \\
\text { Turkey oak } & \text { Quercus laevis Walter } & \text { upland oak } \\
\text { Live oak } & \text { Quercus virginiana Mill. } & \text { mesic oak } \\
\text { Water oak } & \text { Quercus nigra L. } & \text { mesic oak } \\
\text { Laurel oak } & \text { Quercus hemisphaerica Michx. } & \text { mesic oak } \\
\text { Sassafras } & \text { Sassafras albidum (Nutt.) Nees } & \text { fleshy-fruit }{ }^{\dagger} \\
\text { Black cherry } & \text { Prunus serotina Ehrh. } & \text { fleshy-fruit } \\
\text { Persimmon } & \text { Diospyros virginiana L. } & \text { fleshy-fruit } \\
\end{array}$ \\
\hline
\end{tabular}

${ }^{\dagger}$ Indicates species that were only included in shrub-form hardwood tree damage analysis.

Years 1-3). Data collection in Years 1 and 3 was focused on investigating the effects of three guilds of trees on spatially explicit patterns of FRED (hypotheses 1 and 2), but because radiometers were unavailable in Year 1, we predicted FRED in Year 1 by developing a relationship between air temperature and FRED using data from Years 2 to 3. Data collection in Year 2 was focused on understory hardwood fire effects, and we used those data to investigate the relationship between FRED and understory hardwood damage (hypothesis 3). Air temperatures during fire were measured with thermocouples $0.5 \mathrm{~m}$ above ground following Bigelow and Whelan (2019). Radiant energy was measured with custom-built radiometers supported on aluminum poles $5.5 \mathrm{~m}$ above ground. A $0.5 \mathrm{~m}$ cross arm supported the nadir-facing radiometer and data logger. Radiometers consisted of mid-wave (3-5 $\mu \mathrm{m}$, Dexter Research MW) and long-wave (6.5-20 $\mu \mathrm{m}$, Dexter Research LWPSiL2) infrared radiation sensors. Blackbody calibration of the ratio of output voltages of the two sensors allows for the estimation of the emissivity-area, and subsequently for an estimate of the fire radiative flux density for the area within the field of view that is radiating above background (pre-fire) levels (Kremens et al., 2012; Dickinson et al., 2016). The angle of view of the radiometer was $52^{\circ}$ which resulted in a ca. $23 \mathrm{~m}^{2}$ field of view at ground level. Voltages were logged at $1 \mathrm{~Hz}$ and were used to calculate fire radiative flux density which was summed to give an estimate of the total radiant energy emitted during the fire, FRED.

Data were collected during prescribed fires in Years 1-3 (Table 2). Fires were ignited with electric pump-driven drip torches mounted on all-terrain vehicles: backing fires were ignited on the downwind side of each burn unit, then some combination of flanking fires, strip head-fires, and spot fires were ignited to meet the primary burn objective of understory hardwood control. Fuel moisture and weather data were obtained from equipment $<1 \mathrm{~km}$ from study sites and were recorded on a $15 \mathrm{~min}$ interval (Georgia Automated Environmental Monitoring Network, Newton, GA, United States) ${ }^{1}$. We recorded air temperature and heating duration during five fires in January

\footnotetext{
${ }^{1}$ http://www.georgiaweather.net/
} 
TABLE 2 | Average fire weather during experimental prescribed fires (2017-2019) in longleaf pine woodlands in southwest Georgia, United States.

\begin{tabular}{|c|c|c|c|c|c|c|c|}
\hline Year & Date & Start $^{\dagger}$ & End $^{\dagger}$ & Temp. $\left({ }^{\circ} \mathbf{C}\right)^{\ddagger}$ & $\mathbf{R H}(\%)^{\alpha}$ & $W S\left(m s^{-1}\right)^{\beta}$ & FMC $(\%)^{\gamma}$ \\
\hline 1 & January 27 & $12: 21$ & 13:36 & 11 & 46 & 1.9 & 13.4 \\
\hline 1 & January 31 & $10: 51$ & $11: 53$ & 19 & 54 & 2.6 & 13.4 \\
\hline 1 & February 10 & $10: 29$ & $15: 22$ & 15 & 29 & 1.4 & 10.8 \\
\hline 1 & February 13 & $10: 12$ & $14: 40$ & 19 & 33 & 1.7 & 11.6 \\
\hline 1 & February 16 & $10: 53$ & $16: 45$ & 16 & 24 & 1.7 & 9.7 \\
\hline 2 & April 25 & $10: 14$ & $12: 25$ & 22 & 62 & 1.8 & 12.2 \\
\hline 2 & April 26 & $9: 21$ & $11: 19$ & 21 & 65 & 1.8 & 13.5 \\
\hline 2 & April 30 & $11: 24$ & $14: 36$ & 26 & 35 & 1.7 & 7.9 \\
\hline 2 & May 1 & $9: 54$ & $14: 25$ & 27 & 39 & 1.6 & 8.8 \\
\hline 2 & May 2 & $13: 49$ & $15: 02$ & 29 & 30 & 1.6 & 7.3 \\
\hline 2 & May 3 & $10: 12$ & $13: 29$ & 26 & 48 & 1.6 & 8.9 \\
\hline 2 & May 7 & $9: 45$ & $14: 02$ & 28 & 38 & 1.8 & 8.0 \\
\hline 3 & March 28 & $11: 38$ & $14: 25$ & 22 & 36 & 1.7 & 7.4 \\
\hline 3 & April 2 & $14: 12$ & $14: 48$ & 19 & 46 & 1.9 & 11.9 \\
\hline 3 & April 10 & $12: 15$ & $14: 53$ & 27 & 51 & 1.6 & 9.4 \\
\hline 3 & April 16 & $11: 46$ & $12: 27$ & 23 & 29 & 1.5 & 8.7 \\
\hline 3 & April 24 & $11: 03$ & 13:33 & 25 & 47 & 1.6 & 8.1 \\
\hline
\end{tabular}

† Times in 24 h format.

$\ddagger$ Temperature.

a Relative humidity.

$\beta$ Wind speed at $2 m$ height.

$\gamma$ Fuel moisture content of $10 \mathrm{~h}$ fuels.

and February in Year 1 (162 plots); and air temperature, heating duration, and FRED during seven fires in April and May in Year 2 (42 plots), and four fires in April in Year 3 (36 plots).

Data collection in Years 1 and 3 was oriented around individual hardwood trees in a matrix of longleaf pine. Prior to each fire in Year 1, two hardwood trees in each of three size classes and two guilds (upland oak and mesic oak; Table 1) were selected as target trees (18 trees total) and three sample points were distributed around each target tree. One of three sample points was established along each of the azimuths of $0^{\circ}, 120^{\circ}$, and $240^{\circ}$ from each target tree at distances varying from 1 to $20 \mathrm{~m}$ based on the size of the target tree. Distances were 1, 3, and $8 \mathrm{~m}$ from 6 to $14 \mathrm{~cm}$ diameter at breast height (dbh) target trees; 2 , 6 , and $12 \mathrm{~m}$ from 15 to $29 \mathrm{~cm}$ dbh target trees; and 3,10, and $20 \mathrm{~m}$ from target trees $\geq 30 \mathrm{~cm}$ dbh. Distances from target trees were systematically varied by azimuth so that there were similar numbers of samples at each azimuth and distance combination. A single thermocouple was positioned at each sample point. In Year 3, we selected one tree from each of three guilds regardless of size class, and established three thermocouple sample points using the same azimuth and distance methods as in Year 1. In addition to the thermocouple, a radiometer was centered over the sample point.

Sample plots in Year 2 were positioned along a gradient of overstory density. We classified each grid cell as having low, medium, or high overstory abundance index (OAI; Palik et al., 2003). Sample plots were positioned at the centers of randomly selected OAI grid cells, and were equally distributed across OAI classes. Each plot had three thermocouples and a radiometer. Thermocouples were placed within $1 \mathrm{~m}$ of the $23 \mathrm{~m}^{2}$ radiometer field of view and separated radially by $120^{\circ}$.
In all years, we measured $\mathrm{dbh}$, and mapped the location of all trees $>10 \mathrm{~cm}$ dbh within $20 \mathrm{~m}$ of thermocouples or radiometers. Tree $\mathrm{dbh}$ and location were obtained with a GPS receiver (A101 Smart Antenna, Hemisphere GNSS, Scottsdale, AZ, United States) and the Postex DME system with DPII calipers (Haglöf Sweden AB, Långsele, Västernorrland, Sweden). To assess how groundcover structure and composition affect fire behavior, we estimated wiregrass cover and fuel height within $1 \mathrm{~m}$ of each thermocouple. We visually estimated the proportion of the total area covered by wiregrass to the nearest $10 \%$. We also visually estimated the height below which $90 \%$ of fuels were located to the nearest decimeter.

\section{Analysis of Overstory Tree Neighborhood Effects on FRED}

One goal of the study was to explore the relationship between FRED and size, spacing, and composition of overstory trees. We chose FRED as the response variable because it is an effective common currency for fire studies which reflects biomass combusted (Wooster et al., 2005; Kremens et al., 2012), and we hypothesized that the effects of overstory trees on FRED would be mediated by their litter contributions to surface fuels. In Years 2 and $3, \leq 2$ days prior to prescribed burns, we clipped and collected all fuels from $1 \mathrm{~m}^{2}$ sample plots within $2 \mathrm{~m}$ of each radiometer field of view. Fuels were sorted into five classes in Year 2: wiregrass, other forbs and grasses, live woody plants $<2.54 \mathrm{~cm}$ basal diameter, $10 \mathrm{~h}$ fuels (dead, woody material $0.6-2.5 \mathrm{~cm}$ thick), and litter. In Year 3, litter was further sorted into pine needles, oak leaves, and older, partially decomposed litter for a total of seven classes. Fuel samples were dried at $70^{\circ} \mathrm{C}$ for $\geq 48 \mathrm{~h}$ 
and weighed. We calculated the amount of energy in each fuel type using relationships for southeastern pine woodland fuels (Reid and Robertson, 2012). In cases where our fuel types did not directly match fuel types found in Reid and Robertson (2012), we calculated fuel energy using their reported gross energy content for the most similar fuel type. In Year 2, we assumed that the litter would be dominated by pine needles, and calculated fuel energy using gross energy content of pine needle litter. In Year 3 , we used gross energy content of fine litter to calculate energy in older partially decomposed litter. In both years, energy content in wiregrass and other forbs and grasses was calculated using gross energy content of live herbaceous fuels. We used multiple linear regression and relative importance analysis to investigate the relationships between FRED and energy in each fuel type. Relative importance analysis calculates the contribution of each explanatory variable to multiple $\mathrm{R}^{2}$ (Grömping, 2006). Fire radiative energy density was the total infrared radiation emitted during prescribed fire at each sample plot and was calculated from $1-\mathrm{Hz}$ radiative power (MW) measurements summed over the total time of the fire.

Because we were unable to deploy radiometers in all plots, we developed relationships between temperature during fire and radiant energy, and used those relationships to predict FRED from thermocouple data in sample plots where no radiation data were taken. We used data from thermocouple and radiometer pairs in Years 2 and 3 to model linear relationships between temperature and time over $40^{\circ} \mathrm{C}$ and FRED. We calculated a synthetic variable from thermocouple temperature and fire duration by summing numbers of degrees over $40^{\circ} \mathrm{C}$ at each second (TSUM) during prescribed fires. We modeled FRED as a linear function of TSUM.

We used maximum likelihood estimation to evaluate the effects of tree guilds, distance from tree, and tree size on energy release during fire (Canham and Uriarte, 2006). We modeled the effects of overstory tree distance with a negative exponential function Eq. (1) which produces a rapid decline in the effect of a tree with small increases in distance away from the trunk and is commonly used in neighborhood analyses (Canham et al., 2004). We also evaluated a competing function, the Holling type III, which has a sigmoidal form which produces a less steep decline near the trunk Eq. (2). Tree size was expressed as dbh. Based on burning characteristics of their leaf litter, trees were classified into three guilds: longleaf pine, upland oak, and mesic oak (Fonda, 2001; Kane et al., 2008; Table 1). We incorporated the effects of trees $\leq 20 \mathrm{~m}$ from the center of each sample plot on FRED. In the base model we summed the effects of different guilds, and assumed the effect of each guild of tree was additive (i.e., there was no antagonistic or synergistic interactive effect of mixtures of tree guilds). The negative exponential function was expressed as

$$
\text { FRED }=A_{s}+\sum_{i=1}^{n} \sum_{j=1}^{k} \alpha_{i} d b h_{j}^{2} e^{-\beta x_{j}},
$$

where $A$ is a constant that is estimated for different burn seasons, $\mathrm{n}$ is the number of guilds, $\mathrm{k}$ is the number of trees $\leq 20 \mathrm{~m}$ of the sample point, $\alpha$ is a coefficient that determines the sign and magnitude of the effect, and $\beta$ affects how quickly the effect diminishes with distance $\mathrm{x}$. The variables $\mathrm{dbh}$ and $\mathrm{x}$ are the $\mathrm{dbh}$ of the tree and its distance from the measurement device at the center of a sample plot. The Holling type III function was expressed as,

$$
F R E D=A_{s}+\sum_{i=1}^{n} \sum_{j=1}^{k} \alpha_{i} \frac{d b h_{j}^{2} x_{j}^{-2}}{\beta+x_{j}^{-2}},
$$

where $\alpha$ and $\beta$ coefficients are defined as in Eq. (1). We adapted the Holling type III function to fit the pattern of decreasing FRED with distance from a tree by taking the reciprocal of the squared distance. The total effect of tree neighborhood on FRED was the sum of the effects of each tree guild.

To evaluate the possibility of non-additive interactions among tree guilds, we introduced models with antagonistic or synergistic terms (Finzi and Canham, 1998; Bigelow and Canham, 2017). The antagonistic term accounts for the effect of antagonism among tree guilds on the additive term (Holling type III or negative exponential). For each pair of tree guilds:

$$
F R E D=\alpha_{h} v_{h}+\alpha_{l} v_{l}-\left[\frac{\left(\alpha_{h}-\alpha_{l}\right) v_{h} v_{l}}{\alpha_{3}+v_{l}}\right],
$$

where $\alpha_{h}$ and $\alpha_{1}$ are defined as in Eq. (1) and (2) with subscripts corresponding to guilds with higher (more positive) and lower effects on FRED, $v_{h}$ and $v_{l}$ are the sums of the effects of size and distance of neighboring trees in each group [i.e., the elements of Eq. (1) and (2) that follow $\alpha$ ], and $\alpha_{3}$ expresses the magnitude of the antagonistic effect between guild pairs. The total antagonistic term is the sum of antagonism between each pair of tree guilds. The antagonistic term is subtracted from the additive term to give the total effect of tree neighborhood on FRED. The synergistic effect:

$$
F R E D=\alpha_{h} v_{h}+\alpha_{l} v_{l}+\left[\frac{\left(\alpha_{h}-\alpha_{l}\right) v_{h} v_{l}}{\alpha_{3}+v_{h}}\right],
$$

was modeled in the same way as Eq. (3) except the third term was positive, and $\mathrm{v}_{\mathrm{l}}$ in the denominator was substituted for $\mathrm{v}_{\mathrm{h}}$.

Model selection was based on information theory; the best of a series of models of increasing complexity was selected based on Akaike's Information Criterion, corrected for small sample size (Burnham and Anderson, 2002). Error was modeled with a Gamma probability density function because of high variance compared to the mean and because data distributions were right-skewed (Bolker, 2008). The simplest, one-parameter model had no explanatory variables and was equivalent to mean FRED. More complex models allowed for differences in FRED due to the seasonal timing of fire, with different intercept parameters for Years 1 and 3 (dormant- and growing-season, respectively). Further models included variables for the effects of fuel moisture, wiregrass cover within $1 \mathrm{~m}$ of plot center, and height of herbaceous fuels within $1 \mathrm{~m}$ of plot center, as well as their interactive effects with seasonal timing of fire. We did not attempt to analyze all possible main effects and interactions, but instead used a small set of candidate models based on our understanding of the relevant ecological processes (Burnham and Anderson, 2002). Maximum likelihood estimates of model parameters were obtained using simulated annealing, a global optimization algorithm. Simulated annealing searches defined 
parameter ranges to find model parameters that provide the best fit to observations. We searched ranges from -1 to 1 for the $\alpha$ parameter, and from 1 to 50 for the $\beta$ parameter. A uniform number of iterations, $10^{4}$, was used for all model runs. Model adequacy was addressed in part by examination of residuals with respect to day, year, and $\mathrm{x}, \mathrm{y}$ burn unit location. Analyses were done in $\mathrm{R}$ statistical software using the "Likelihood" package (Murphy, 2015; R Core Team, 2020).

\section{FRED as Predictor of Hardwood Top-Kill}

Because control of shrub-form hardwoods is a common objective for prescribed fire in longleaf woodlands, we investigated how FRED affected post-fire fate of four guilds of shrubform hardwood trees common in the understory of longleaf pine woodlands. We expanded guild definitions beyond the categories used for overstory trees to fleshy-fruited hardwoods, mesic oaks, upland oaks, and sandhill oaks, because understory hardwood species richness was higher than in the overstory. We measured height and basal diameter of shrub-form hardwoods within the field of view of each radiometer. Our goal was to get measurements on one shrub-form tree from each guild at each radiometer, but where that was not feasible we took measurements of trees from each guild that was represented. Two to three weeks post-fire, we inspected each tree and assigned a fate. Post-fire fates in order of increasing severity were as follow: no visible damage ("green"); all leaves scorched, but new growth in the crown ("crown sprouts"); all leaves scorched with new stems sprouting at or below ground line ("top-kill"); or all leaves scorched with no new growth ("dead"). We also sought to understand how bark thickness might confer fire resistance to shrub-form hardwood tree stems, so following inspection, we cut each stem at $10 \mathrm{~cm}$ height and measured bark thickness under a dissecting microscope.

We used proportional-odds models in $\mathrm{R}$ statistical software with the "ordinal" package to identify factors that influenced shrub-form hardwood post-fire fate (Christensen, 2015; R Core Team, 2020). Proportional-odds models fit series of logistic regressions to thresholds that correspond to ordinal levels of a response, and estimate the proportions of data above and below each threshold. We included FRED, shrub-form hardwood tree height, and guild as explanatory variables for models of shrubform hardwood post-fire fate. Shrub-form tree stem radius at $10 \mathrm{~cm}$ height and bark thickness were excluded as explanatory variables because of high correlation $\left(r^{2}>70 \%\right)$ with shrubform tree height. To visualize the effects of significant explanatory variables and interactions on shrub-form hardwood post-fire fate, we calculated post-fire fate probabilities at three levels of FRED that spanned the range of predicted effects of different overstory tree guilds and fire seasons.

\section{RESULTS}

\section{Prediction of FRED and Relationship to Fuel Energy}

The synthetic variable TSUM accounted for 36\% of the variation in FRED $(p<0.001)$. The linear regression was
FRED $=0.27+7.1 \times 10^{-5}$. TSUM. We used this relationship to predict FRED for thermocouples that were not co-located with radiometers, and subsequent analyses using FRED either as a predictor or response variable were done with measured and predicted FRED. We measured FRED with radiometers at 29 sample points and predicted FRED for 193 sample points. Mean FRED during experimental, dormant-season prescribed fires in Year 1 calculated from the linear relationship between TSUM and FRED was $0.79 \mathrm{MJ} \mathrm{m}^{-2}$ (standard deviation $0.43 \mathrm{MJ}$ $\mathrm{m}^{-2}$ ), and mean FRED during experimental, growing-season prescribed fires in Year 3 measured directly by radiometers was $1.25 \mathrm{MJ} \mathrm{m}^{-2}\left(0.90 \mathrm{MJ} \mathrm{m}^{-2}\right)$.

Mean fuel load across sample plots in Years 2 and 3 was 6.1 (standard deviation 2.2) $\mathrm{Mg} \mathrm{ha}^{-1}$. In Year 2, FRED accounted for $42 \%$ of the variation in total fuel energy (Table 3 ). That relationship was worse in Year 3 when virtually none of the variation in total fuel energy was explained by FRED (adjusted $R^{2}=-0.01$ ). When the data from Year 2 and 3 were combined, the interactive effect of total fuel energy by year accounted for $32 \%$ of variation in FRED. Analysis of different fuel types revealed that litter made the highest energy contribution to FRED, but that relationship was weaker in Year 3 than in Year 2 (multiple $\mathrm{R}^{2} 0.13$ and 0.53 , respectively, Table 4). The overall relationship between fuel energy and FRED was also weaker in 2019 than in 2018 (multiple $\mathrm{R}^{2} 0.33$ and 0.62 , respectively).

\section{Neighborhood Models of FRED}

Neighborhood analysis of prescribed fire data revealed that overstory tree guild, and interactive effects of fuel moisture with season of burn, and wiregrass with season of burn were important predictors of FRED. Height of herbaceous fuel did not have an effect, and there was little evidence of antagonism or synergism among tree guilds (Table 5). Estimation of intercepts by season of burn decreased $\mathrm{AIC}_{\mathrm{c}}$ by 19 units compared to the interceptonly model and accounted for an additional $11 \%$ of the variation in FRED. The negative exponential and the Holling type III functions fit the data similarly, both accounting for an additional $6 \%$ of the variation in FRED and decreasing $\mathrm{AIC}_{\mathrm{c}}$ by 22 units. The best fits for both model functions included separate intercepts by

TABLE 3 | Results of linear regressions predicting total energy in fuels $\left(\mathrm{KJ} \mathrm{m}^{-2}\right)$ as a function of FRED during prescribed fire in longleaf pine woodlands in southwest Georgia, United States.

\begin{tabular}{lccccc}
\hline Parameter & Estimate & SE & t-value & $\boldsymbol{p}$-value & $\boldsymbol{R}^{\mathbf{2}}$ \\
\hline Year 2 & & & & & \\
Intercept & 7476.19 & 1675.31 & 4.46 & $<0.001$ & \\
FRED & 5.96 & 1.14 & 5.22 & $<0.001$ & 0.42 \\
Year 3 & & & & & \\
Intercept & 11195.89 & 1914.61 & 5.85 & $<0.001$ & \\
FRED & 1.55 & 1.74 & 0.89 & 0.379 & -0.01 \\
Year 2 and 3 & & & & & \\
Intercept & 7476.19 & 1598.44 & 4.68 & $<0.001$ & \\
FRED & 5.96 & 1.09 & 5.47 & $<0.001$ & \\
Year & 3719.70 & 2599.48 & 1.43 & 0.157 & \\
FRED $\times$ Year & -4.40 & 2.16 & -2.04 & 0.045 & 0.32
\end{tabular}


TABLE 4 | Relative importance (non-normalized contribution to multiple-r ${ }^{2}$ in linear regression) of energy in surface fuel types in $1 \mathrm{~m}^{2}$ plots as predictors of FRED in prescribed fires in longleaf pine woodlands in southwest Georgia, United States (relative importance $\geq 0.10$ indicated by bold font).

\begin{tabular}{lcc}
\hline Predictor & Year 2 & Year 3 \\
\hline Litter $^{\dagger}$ & $\mathbf{0 . 5 3 0}$ & $\mathbf{0 . 1 3 4}$ \\
$10-\mathrm{h}$ & 0.040 & 0.072 \\
Wiregrass & 0.031 & 0.004 \\
forbs/grasses & 0.021 & 0.016 \\
Live woody & 0.003 & 0.092 \\
Pine needles & $\mathrm{NA}$ & 0.009 \\
Oak leaves & $\mathrm{NA}$ & 0.005 \\
Total $r^{2}$ & 0.624 & 0.332 \\
\hline
\end{tabular}

† Intact pine needle and oak leaf litter were not separated from other, partially decomposed litter in Year 2 as they were in Year 3.

TABLE 5 | Comparison of neighborhood models for prediction of FRED during experimental prescribed fires in longleaf pine woodlands in southwest Georgia, United States (bold font indicates AlC-best model).

\begin{tabular}{|c|c|c|c|c|c|}
\hline Model $^{\dagger}$ & $\boldsymbol{K}^{\ddagger}$ & $L^{\alpha}$ & $R^{2 \beta}$ & $A / C_{c}^{\gamma}$ & $\Delta_{i}^{\delta}$ \\
\hline Intercept only (null) & 2 & -1682.05 & 0 & 3368.15 & 65.74 \\
\hline Season & 3 & -1671.66 & 0.11 & 3349.426 & 47.02 \\
\hline Holling Type III (H3) & 7 & -1656.24 & 0.19 & 3327.007 & 24.6 \\
\hline Negative exponential & 7 & -1656.32 & 0.19 & 3327.154 & 24.74 \\
\hline $\mathrm{H} 3+\mathrm{FMC} \times$ Season & 9 & -1644.55 & 0.27 & 3307.943 & 5.53 \\
\hline $\begin{array}{l}\text { H3 + FMC } \times \text { Season }+ \text { WG } \\
\times \text { Season }\end{array}$ & 11 & -1639.58 & 0.31 & 3302.411 & 0.00 \\
\hline $\begin{array}{l}\mathrm{H} 3+\text { ant. }^{\varepsilon}+\mathrm{FMC} \times \text { Season }+ \\
\text { WG } \times \text { Season }\end{array}$ & 12 & -1639.87 & 0.31 & 3305.226 & 2.82 \\
\hline $\begin{array}{l}\mathrm{H} 3+\text { syn }^{\varepsilon}+\mathrm{FMC} \times \text { Season } \\
+\mathrm{WG} \times \text { Season }\end{array}$ & 12 & -1638.63 & 0.32 & 3302.753 & 0.34 \\
\hline
\end{tabular}

† Season, season of burn (dormant- or growing-season); FMC, fuel moisture content, WG, wiregrass cover.

‡ Number of estimated parameters (includes parameter for probability density function).

${ }^{\alpha}$ Maximum log-likelihood.

${ }^{\beta} R^{2}$, adjusted $R$-squared.

$\gamma$ Akaike's Information Criterion corrected for small sample size.

$\delta$ Difference in $A / C_{C}$ from the model with the lowest $A / C c$; indicates strength of support compared to best model $\left(\Delta_{i}<2=\right.$ substantial support, $4<\Delta_{i}<7=$ considerably less support, and $\Delta_{i}>10$ essentially no support; Burnham and Anderson, 2002).

${ }^{\varepsilon}$ Indicates functional form to model antagonism or synergism.

season of burn, $\alpha$ parameters estimated by guild, and a single $\beta$ parameter (Figure 1 and Tables 5, 6). The inclusion of the interactive effect of fuel moisture and season of burn decreased $\mathrm{AIC}_{\mathrm{C}}$ by 19 and accounted for an additional $8 \%$ of the variation in FRED, and the addition of the interactive effect of wiregrass cover with season of burn decreased $\mathrm{AIC}_{\mathrm{c}}$ by 6 and accounted for an additional $6 \%$ of the variation in FRED. Neither the interaction between height of herbaceous fuel and season of burn nor the simple effect of height of herbaceous fuel reduced $\mathrm{AIC}_{\mathrm{c}}$. Inclusion of antagonistic or synergistic terms to negative exponential and Holling type III models increased AIC from 1 to 3 units and did not account for any additional variation in FRED, therefore we did not consider antagonistic or synergistic effects further. The best models fit were negative exponential and Holling type III

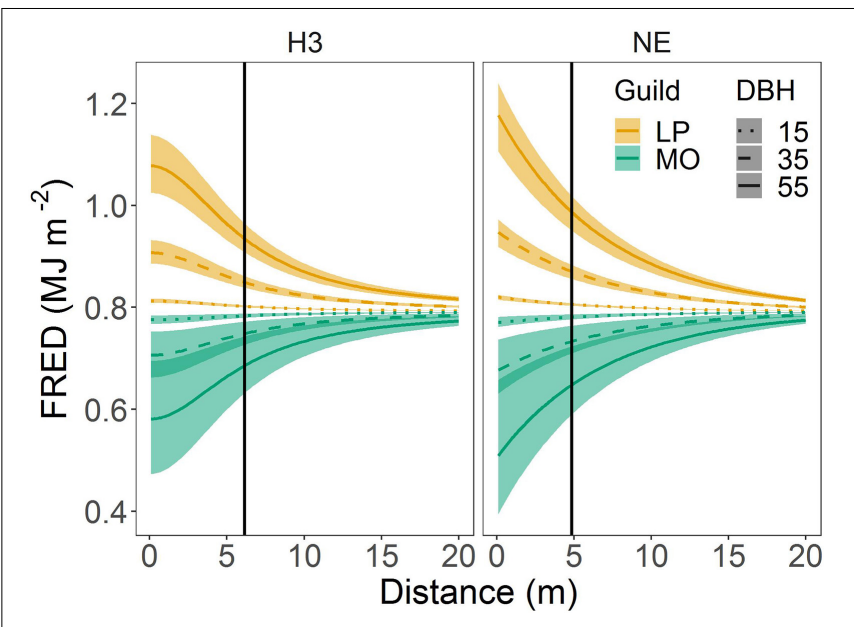

FIGURE 1 | Neighborhood models [Holling type III (left panel) and negative exponential (right panel)] illustrating effect of distance from tree (two guilds and three DBH sizes) on predicted FRED from prescribed fires in longleaf pine woodlands in southwest Georgia, United States (shaded area indicates 2 AIC unit support interval). Vertical lines represent the distance at which the effect of a tree was half its maximum. Guild abbreviations are LP, longleaf pine; MO, mesic oaks.

TABLE 6 | Parameter estimates ( $\pm 2 \mathrm{AlC}_{\mathrm{c}}$ unit support limits) for negative exponential and Holling type III models of the effects of the proximity of three guilds of trees on FRED during prescribed fires in longleaf pine woodlands in southwest Georgia, United States.

\begin{tabular}{lcc}
\hline Parameter & Negative exponential & Holling type III \\
\hline Longleaf pine $\alpha$ & $0.129(0.106,0.150)$ & $0.095(0.077,0.115)$ \\
Upland oak $\alpha$ & $0.042(-0.017,0.092)$ & $0.027(-0.021,0.069)$ \\
Mesic oak $\alpha$ & $-0.095(-0.133,-0.045)$ & $-0.070(-0.105,-0.032)$ \\
$\beta$ & $14.249(12.825,16.536)$ & $16.236(13.965,19.1)$ \\
\hline
\end{tabular}

functions with tree guilds treated as additive effects. These models accounted for $32 \%$ and $31 \%$ of the variation in FRED and were separated by only 0.28 AIC units; we consider these model fits to be equivalent. Examination of model residuals did not show a pattern with respect to plot latitude and longitude, but revealed a pattern by burn date. We found significantly higher, positive residuals on January 31 in Year 1, and March 28 in Year 3.

The best models predicted ambient FRED (i.e., at the distance where overstory effects reduce to 0 ) with average fuel moisture, wiregrass cover, and ambient temperature to be $0.59 \mathrm{MJ} \mathrm{m}^{-2}$ $\left( \pm 2 \mathrm{AIC}_{\mathrm{c}}\right.$ support interval $0.44-0.76 \mathrm{MJ} \mathrm{m}^{-2}$ ) when burns were conducted in the dormant-season, and $0.92 \mathrm{MJ} \mathrm{m}^{-2}$ (0.65$1.21 \mathrm{MJ} \mathrm{m}^{-2}$ ) when burns were conducted during the growing season. The effects of wiregrass cover and fuel moisture content varied by season of burn. During dormant-season fires, wiregrass cover and fuel moisture content were positively correlated with FRED, but during growing-season fires, wiregrass cover and fuel moisture content were negatively correlated with FRED (Table 7). The effect of overstory on FRED did not vary by fire season, having the same effect relative to ambient FRED during dormant- and growing-season fires (Years 1 and 3, respectively; Table 5). Predicted FRED increased with proximity to longleaf 
TABLE 7 | Effects of wiregrass cover and fuel moisture content by season of burn (Year 1 = dormant, Year 3 = growing) on FRED during experimental burns in longleaf pine forests in southwest Georgia, United States.

\begin{tabular}{lcc}
\hline Fuel moisture & Year & FRED $\left.\mathbf{( M J ~ m}^{-\mathbf{2}}\right)^{\dagger}$ \\
\hline low & 1 & $0.16(0.04,0.31)$ \\
high & 1 & $0.67(0.52,0.84)$ \\
low & 3 & $1.26(0.98,1.58)$ \\
high & 3 & $-0.09(-0.45,0.33)$ \\
\hline Wiregrass cover & Year & FRED (MJ m $\left.{ }^{-2}\right)$ \\
\hline low & 1 & $0.46(0.36,0.58)$ \\
high & 1 & $0.6(0.42,0.81)$ \\
low & 3 & $1.12(0.88,1.39)$ \\
high & 3 & $0.64(0.29,1.05)$ \\
\hline
\end{tabular}

Effects were predicted at high and low fuel moisture contents of $0.07 \%$ and $0.14 \%$, and at high and low wiregrass cover of $20 \%$ and $80 \%$.

${ }^{\dagger}$ FRED ( \pm 2 AlC unit support intervals).

pine and upland oaks but decreased with proximity to mesic oaks (Figure 1). The negative exponential function predicted a larger maximum effect of a tree than the Holling type III function, but the overall pattern of decrease in FRED with distance was similar. For instance, average FRED for prescribed fires in Years 1 and 3 was $0.79 \mathrm{MJ} \mathrm{m}^{-2}$. FRED at the base of a $55 \mathrm{~cm} \mathrm{DBH}$ longleaf pine, upland oak, or mesic oak predicted by the negative exponential function was $1.18,0.92$, and $0.51 \mathrm{MJ} \mathrm{m}^{-2}$, respectively, and was $1.08,0.87$, and $0.58 \mathrm{MJ} \mathrm{m}^{-2}$, respectively, when predicted with the Holling type III function. At $10 \mathrm{~m}$, predictions for a $55 \mathrm{~cm}$ $\mathrm{DBH}$ longleaf pine, upland oak, and mesic oak from the negative exponential function were $0.87,0.81$, and $0.73 \mathrm{MJ} \mathrm{m}^{-2}$, and were $0.86,0.82$, and $0.72 \mathrm{MJ} \mathrm{m}^{-2}$ from the Holling type III function. The effects for smaller diameter trees followed the same patterns as $55 \mathrm{~cm} \mathrm{DBH}$ trees but were smaller in magnitude.

\section{Shrub-Form Hardwood Post-fire Fate}

Proportional odds models indicated that FRED and shrubform tree height by guild had significant effects on shrubform hardwood post-fire fate (Table 8). The inclusion of FRED resulted in the largest difference attributable to a single explanatory variable, decreasing $\mathrm{AIC}_{\mathrm{c}}$ by 46.35 from the mean model. Inclusion of shrub-form tree height and guild decreased $\mathrm{AIC}_{\mathrm{c}}$ by an additional 22.73 and 9.48 units, respectively. The best model included FRED and an interaction between shrubform hardwood tree guild and height, decreasing $\mathrm{AIC}_{\mathrm{c}}$ an additional 12.05 units.

As FRED increased, a larger proportion of shrub-form hardwood trees was top-killed or killed completely, and this was true regardless of guild (Figure 2). We predicted probability of shrub-form hardwood fate at four levels of FRED that correspond to a range of predicted influence of overstory trees and fireseason on FRED. At the first level, during dormant-season fire with the influence of a $55 \mathrm{~cm} \mathrm{DBH}$ mesic oak within $1 \mathrm{~m}$, predicted FRED was $0.35 \mathrm{MJ} \mathrm{m}^{-2}$, and the probability of shrubform hardwood top-kill or death was 0.41 . At the second level, mean FRED during growing-season fires was $0.79 \mathrm{MJ} \mathrm{m}^{-2}$, and the probability of top-kill or death was 0.67 . At the third
TABLE 8 | Comparison of proportional odds models for fate of shrub-form hardwood trees following experimental prescribed fire in longleaf pine woodlands in southwest Georgia, United States (bold font indicates AIC-best model).

\begin{tabular}{lcccc}
\hline Model & $\boldsymbol{K}^{\dagger}$ & $\boldsymbol{L}$ & $\boldsymbol{A I C}_{\boldsymbol{c}}$ & $\boldsymbol{\Delta}_{\boldsymbol{i}}$ \\
\hline Intercept-only (null) & 3 & -137.42 & 280.84 & 81.13 \\
FRED & 4 & -113.24 & 234.49 & 34.78 \\
FRED + Height & 5 & -100.88 & 211.76 & 12.05 \\
FRED + Height + Guild & 8 & -93.14 & 202.28 & 2.57 \\
FRED + Guild $\times$ Height & $\mathbf{7}$ & $-\mathbf{9 1 . 8 5}$ & $\mathbf{1 9 9 . 7 1}$ & $\mathbf{0}$ \\
\hline
\end{tabular}

† See Table 5 footnotes for meaning of column headings.

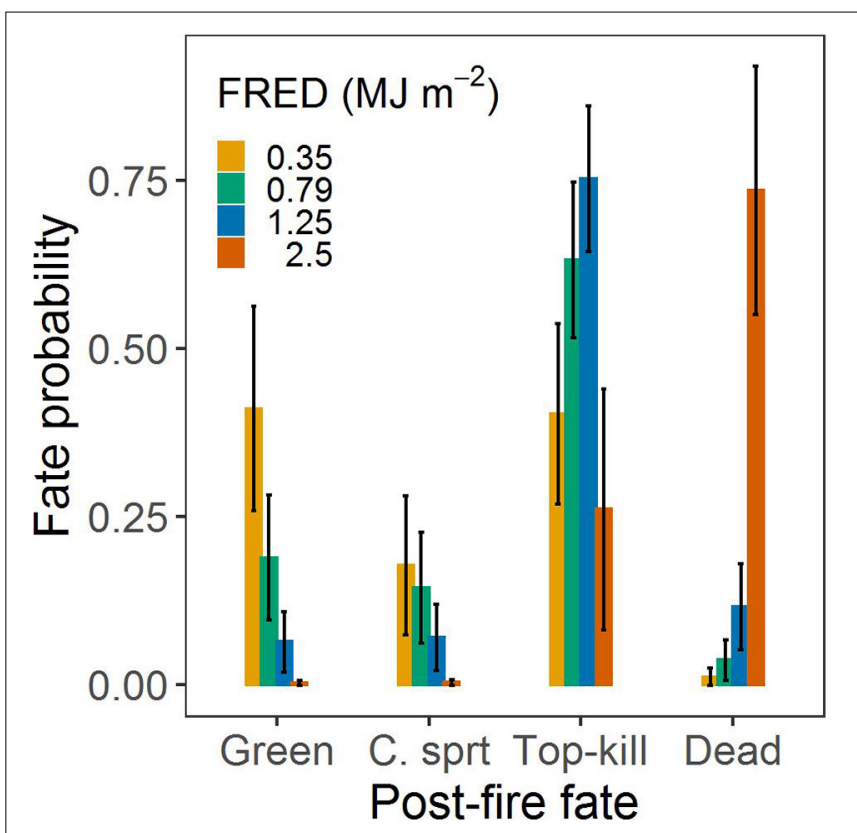

FIGURE 2 | Predicted probability (narrow vertical lines indicate 95\% confidence limits) of four possible fates of shrub-form hardwood trees at five levels of FRED that span a range of fire intensity from experimental prescribed fires in longleaf pine woodlands in southwest Georgia, United States.

Probabilities are averaged over all guilds, and probabilities of each fate at each level of FRED sum to 1. Post-fire fates are "Green," functional green leaves remaining in crown; "C. sprt," complete scorch with new sprouts from the crown; "Top-kill," complete scorch with new sprouts from the base; "Dead," complete scorch with no new sprouts.

level, mean growing-season FRED was $1.25 \mathrm{MJ} \mathrm{m}^{-2}$, and the probability of top-kill or death was 0.87 . Finally, during dormantor growing-season fire with continuous longleaf pine canopy, predicted FRED was $2.5 \mathrm{MJ} \mathrm{m}^{-2}$, and shrub-form hardwood top-kill or death probability was 0.995 .

The effect of shrub-form tree height on post-fire fate interacted with guild; as height increased, shrub-form trees were less likely to suffer top-kill or death (Figure 3). That effect was stronger for upland and sandhill oaks than for fleshy-fruited hardwoods and mesic oaks. When FRED was $0.35 \mathrm{MJ} \mathrm{m}^{-2}$, the most common fate for $0.5 \mathrm{~m}$ tall shrub form hardwoods regardless of guild was top-kill. For $2 \mathrm{~m}$ tall hardwoods, the probability that upland and sandhill oaks would survive fire with functional leaves or with new leaves sprouted from buds in the crown was 0.86 and 


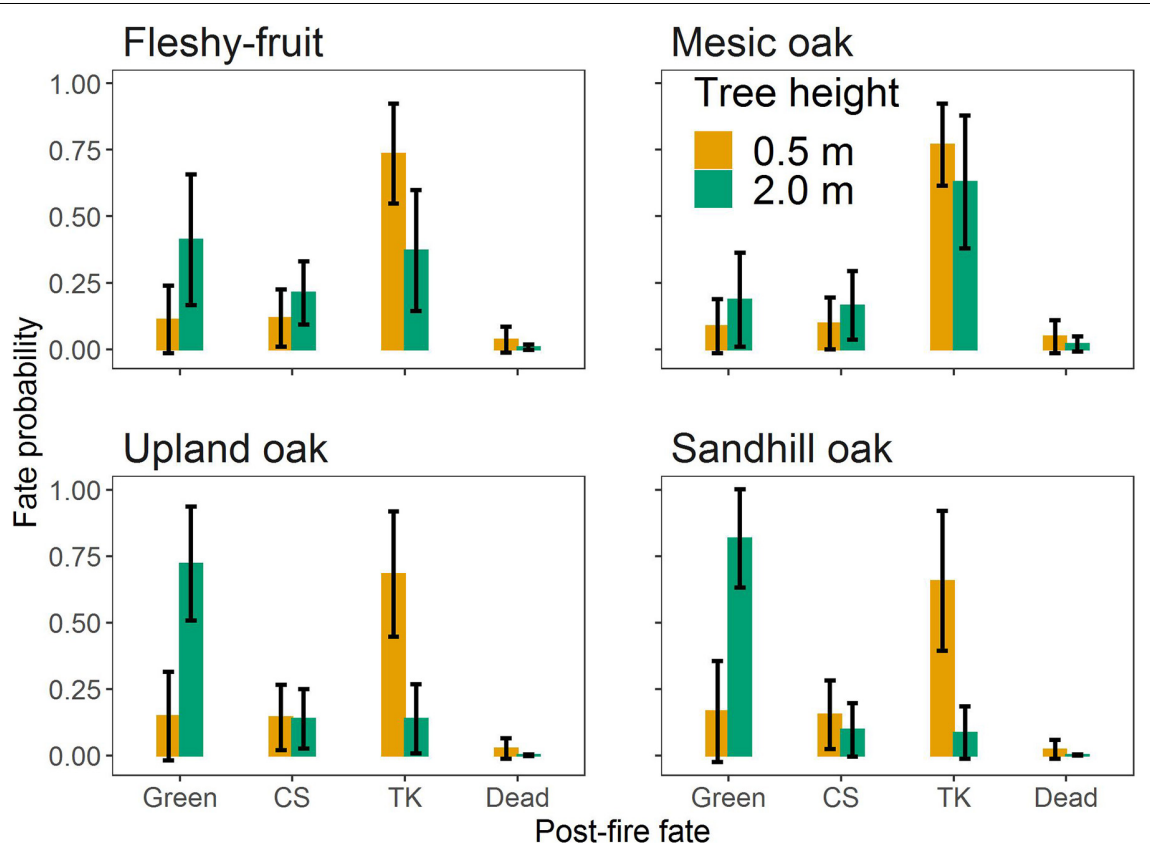

FIGURE 3 | Predicted probability (narrow bars indicate 95\% confidence limits) of post-prescribed-fire fate of shrub-form hardwood trees 0.5 and $2.0 \mathrm{~m}$ in height in longleaf pine woodlands in southwest Georgia, United States. Probabilities were calculated based on a low FRED $\left(0.35 \mathrm{MJ} \mathrm{m}^{-2}\right)$. See Figure 2 for fate definitions.

0.92, but with fleshy-fruited hardwoods and mesic oaks those probabilities were reduced to 0.62 and 0.35 , respectively.

\section{DISCUSSION}

Our study extended a novel application of maximum likelihood neighborhood models of prescribed fire behavior (Bigelow and Whelan, 2019), to a multiple-guild scenario in which nonadditive effects were tested for. Positive non-additive effects of species mixtures have been widely reported based on laboratory analyses (de Magalhães and Schwilk, 2012; Blauw et al., 2015; Della Rocca et al., 2018; Zhao et al., 2019; Gormley et al., 2020), but our in situ, field-based analyses provided no evidence for non-additive mixture effects on modeled FRED. Incorporating hardwoods (upland oaks vs. mesic habitat oaks of longleaf pine woodland) showed that neighborhood models of FRED work well for these guilds, and that mesic oaks have a negative influence on FRED. The range of energy release values predicted from our models in mapped stands was sufficient to generate variation in top-kill mortality and hardwood species composition and regeneration based on our study of modeled FRED and top-kill.

Several factors may have limited the explanatory power of our neighborhood analysis of FRED, which had maximum $\mathrm{R}^{2}$ of 0.32 . Fuel moisture is a critically important variable governing fire behavior (Loudermilk et al., 2017), and we used a bulk moisture content rather than measuring moisture content of fuel types that dry at different rates and have different effects on fire behavior (e.g., wiregrass, herbaceous species, hardwood leaves, and longleaf pine needles; Nelson and Hiers, 2008; Kirkman and Giencke, 2017). Unburned fuels in radiometer footprints were not accounted for. Energy in unburned fuel cannot be measured by radiometers, and likely increased variability in estimates of the effect of canopy-derived litter on FRED. This was especially evident in sample plots burned on March 28 in Year 3 following Hurricane Michael in October, 2018 (Andrew Whelan, personal observation). Abundant coarse woody debris resulted in uneven burn patterns because crews could not ignite fires inside burn units, which led to areas of unburned fuel (Scott Smith, personal communication). Increased fuel variation coupled with spatial separation of clip plots and radiometer plots likely contributed to high model residuals and low predicted FRED in plots burned on March 28 in Year 3. Likelihood models of overstory tree effects assume a consistent groundcover fuelbed to which overstory tree effects are added. Large branches and tree crowns blown down during high wind events are large deposits of litter and coarse woody fuels that are not accounted for by our model. Wind speed during prescribed fires may have contributed to high model residuals in plots burned on January 31 in Year 1. Wind speeds during that prescribed fire were higher than during any other prescribed fire in this study. Higher winds likely created higher fireline intensity, and our model did not incorporate wind-driven effects on fire behavior. Additional variation accounted for by these variables would improve predictions of FRED.

We compared fuel loads and FRED from the present study with those from an earlier series of prescribed fire experiments in longleaf pine woodlands (Table 9; Ottmar and Restaino, 2014). There were some differences in the relative contributions of herbaceous, shrub, and litter components compared to those from the earlier study, but total fuel loads and FRED were

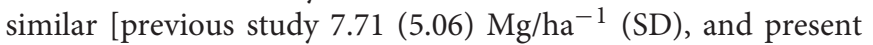
study 7.63 (3.24) $\left.\mathrm{Mg} / \mathrm{ha}^{-1}\right]$. Differences are likely related to 
TABLE 9 | Comparison of fuel loads and FRED between RxCADRE study in sandhill longleaf woodland (Ottmar and Restaino, 2014) and the current study in upland longleaf woodland (means and standard deviations).

\begin{tabular}{lcc}
\hline & \multicolumn{2}{c}{ Fuel load (Mg ha ${ }^{-\mathbf{1}}$ ) } \\
\cline { 2 - 3 } Fuel type & RxCADRE & Current \\
\hline Herb & $0.77(0.75)$ & $3.24(2.42)$ \\
Shrub & $1.6(3.71)$ & $0.51(0.55)$ \\
Coarse woody debris & $1.5(2.08)$ & $1.51(1.7)$ \\
Litter & $3.84(2.39)$ & $2.38(1.77)$ \\
Combined & $7.71(5.06)$ & $7.63(3.24)$ \\
& & FRED (MJ m \\
& & \\
Season & RxCADRE & Current \\
Dormant & $0.86(0.39)$ & $0.79(0.43)$ \\
Spring and Fall & $1.44(0.89)^{\dagger}$ & $1.25(0.92)^{\ddagger}$ \\
\hline
\end{tabular}

† Fires conducted in November 2012.

$\ddagger$ Fires conducted in April 2019.

forest structure. Half of the prescribed fires in forested areas in the earlier experiments were conducted in longleaf pine sandhills, which typically feature sparser groundcover and a better-developed, xeric-oak-dominated midstory than upland longleaf pine woodlands (Rodgers and Provencher, 1999). Similar total fuel loads and mean FRED from the two studies indicate that fuelbeds common to diverse types of longleaf pine woodlands may burn with similar intensity.

Overstory effects must be considered in context with the fire environment including fire weather and fuel moisture. Fire season, fuel moisture, and wiregrass cover explained substantial variation in FRED in the present study, and their combustion represents a baseline of fire behavior upon which the effects of overstory litter deposition act. Higher FRED during growingseason fire may be indirectly due to higher ambient temperatures which could increase vapor pressure deficit and the drying power of the air, leading to lower fuel moisture. Lower fuel moisture means less energy required to heat fuels to ignition during growing-season fire, which might leave more energy to be emitted as radiant energy (Mcallister and Weise, 2017). Apparently contradictory results of positive relationships of wiregrass and fuel moisture with FRED in Year 1 (dormant season), but negative relationships in Year 3 (growing season) may be partially explained by how prescribed fires are conducted in relation to wiregrass abundance. Fire practitioners are keenly aware of wiregrass' burning characteristics. Wiregrass burns intensely and has been linked with increased flame length and maximum air temperature during fire, but its most crucial burning characteristic may be the wide range of fuel moisture under which it burns (Fill et al., 2016; Bigelow and Whelan, 2019). During the growing season, the risk of crown scorch is higher, and areas with high wiregrass cover are therefore often burned at relatively high fuel moisture (Mark Melvin, personal communication), but less caution is used for wiregrass cover during the dormant-season when the risk of crown scorch is lower.

\section{Feedbacks to FRED}

Overstory tree species can modify their surrounding
(Canham et al., 1994), and they influence fire in longleaf pine woodlands (Platt et al., 2016). Tree species with traits that protect them from frequent fire tend to also produce litter that promotes frequent fire (Schwilk, 2003; Varner et al., 2016). Increased FRED with proximity to longleaf pine and upland oak species, and decreased FRED with proximity to mesic oak species, clearly illustrates this relationship. These patterns are consistent with patterns of exponential decrease of overstory litter deposition from a variety of conifer and broadleaf species (Ferrari and Sugita, 1996). Ambiguity as to which functional form, negative exponential or Holling type III, better fit the FRED data may be related to leaf dispersal characteristics. Similar work showing a pattern of maximum leaf deposition at the trunks of trees with smaller leaves, but maximum leaf deposition from 4 to $11 \mathrm{~m}$ away from larger-leaved trees, suggests that the negative exponential function may be a better fit to longleaf pine and mesic oaks, and the Holling type III may be a better fit to upland oaks (Bigelow and Canham, 2015).

The sign and magnitude of the overstory effect on FRED reflects the burning characteristics of litter from different overstory guilds: longleaf pine litter burns more intensely than upland oak litter, which in turn burns more intensely than mesic oak litter (Fonda, 2001; Kane et al., 2008). The burning properties of different guilds of overstory-derived litter may not be the only mode of influence. In fire-regulated woodlands, crown structure and leaf morphology can affect fuel bed composition and moisture content (Babl et al., 2020). Longleaf pine leaf area is lower than a wide variety of oak species common in longleaf pine woodlands (Teske and Thistle, 2004; Addington et al., 2006). Reduced light transmission through oak canopies may have contributed to lower FRED by reducing understory growth, and would likely have a strong, negative effect on wiregrass cover (a C4 species). As discussed previously, this could result in the loss of a fuel structure that burns well. As a fire-regulated ecosystem, changes in fire behavior in longleaf pine woodlands could have strong effects on overstory structure and composition.

\section{Non-additive Effects}

Although non-additivity has been found in multi-species fuel mixtures on fire behavior metrics such as spread rate, flame height, and flame duration (de Magalhães and Schwilk, 2012; Blauw et al., 2015; Della Rocca et al., 2018; Zhao et al., 2019; Gormley et al., 2020), these non-additive effects may not constitute true interactions in the sense that one species directly enhances or inhibits the other (i.e., a complementarity effect). van Altena et al. (2012) conjecture that the characteristics of one species overrides those of the others, a phenomenon they call enhanced dominance. Research into non-additivity with regard to fundamental physical factors that cause fire effects (e.g., heat energy release) has largely not found non-additivity; effects can be predicted from the respective mass of the component species (de Magalhães and Schwilk, 2012; Della Rocca et al., 2018). Our findings of absence of non-additive effects were consistent with these findings. Our methods differed from the studies above in that we did not create or measure fuel mixes directly, instead we used tree neighborhood as an indirect measure of tree effect on fuel-beds in situ. This method, although less certain with respect to fuel-bed mass and composition, offers the advantage 
of incorporating indirect effects of trees on fuel beds and fire conditions via differing radiation transmission through their crowns (Canham et al., 1994; Babl et al., 2020), and competition against ground-cover and understory plants.

Overstory-derived litter is only one component of natural fuel configurations that are compositionally and structurally complex. In longleaf pine woodlands, xeric and upland oak litter, longleaf pine litter, and wiregrass have all been shown to burn intensely (e.g., long flame length and burn time; Varner et al., 2015), and mixtures of both longleaf pine and hardwood litter with wiregrass have been found to increase duration of flaming and smoldering (Fill et al., 2016). Although it has been postulated that wiregrass and longleaf pine needle litter create a fuel structure that burns exceptionally well (Hendricks et al., 2002), research suggests that no synergy occurs (Bigelow and Whelan, 2019). A more thorough investigation of effects of different components of the fuel load would refine our understanding of how fuel composition and structure affect fire intensity.

\section{Shrub-Form Hardwoods}

Shrub-form hardwoods in longleaf pine woodlands are regulated by fire and are influenced by patterns of fire intensity (Glitzenstein et al., 1995; Whelan et al., 2018). The factors we have identified that influence FRED implicitly affect shrubform hardwood demographics, because higher energy release during fire causes more damage to shrub-form hardwoods. Season of fire had a striking effect on FRED, consistent with the well-established phenomenon of increased top-kill and death following growing-season burns (Boyer, 1993; Glitzenstein et al., 1995). Similarly, it has long been understood that drier fuels burn more intensely, and despite inconsistent results on the effect of fuel moisture on FRED, fires burning in fuels with lower fuel moisture content should burn more intensely and are likely to cause more damage to shrub-form hardwoods (Loudermilk et al., 2017). Though the effect of wiregrass cover on FRED within season was not significant, wiregrass has been shown to negatively affect understory hardwood trees in longleaf pine woodlands; that effect may be due to a combination of fire effects and competition. Fill et al. (2017) found that 20 years after wiregrass planting, the occurrence of understory hardwood stems in a longleaf pine forest in South Carolina was substantially reduced, but because the sample stands had not been regularly burned, they were uncertain of how much of the reduction was related to fire effects versus competition. Overstory tree neighborhood affects shrubform hardwoods through its effects on fire intensity as well. Recruitment of shrub-form hardwoods into larger size classes in longleaf pine canopy openings is well documented (Jack et al., 2006; Bigelow and Whelan, 2019). Like wiregrass, the effect of longleaf pine overstory on shrub-form hardwoods is mediated by both fire and competition (Pecot et al., 2007), but the abundance of shrub-form hardwoods under unbroken longleaf pine canopy suggests the overriding factor is fire (Williamson and Black, 1981; Platt et al., 2016).

One goal of prescribed fire in longleaf pine woodlands is to prevent shrub-form hardwoods from creating a closed midor overstory canopy by top-killing or completely killing them. Shrub-form hardwoods can persist in a cycle of top-kill and regrowth over multiple prescribed fires (Grady and Hoffmann, 2012). While larger shrub-form hardwoods are more resistant to fire damage and more likely to grow into the overstory, the factors that govern the size attained by a shrub-form hardwood during a fire-free interval may not be. Growing-season fire has often been observed to provide more effective hardwood control than dormant season fire; one proposed mechanism is that carbohydrate reserves may be depleted by leaf expansion, leaving insufficient reserves if leaves must be replaced shortly thereafter (Boyer, 1993; Glitzenstein et al., 1995; Robertson and Hmielowski, 2014). Another study found no difference in hardwood survival with respect to growing season fire (Whelan et al., 2018), and there was no support for the carbohydrate depletion hypothesis in a study in which reserves were assayed (Ruswick et al., 2021). Authors of the latter study emphasize that fire heat determines fire effects, suggesting that seasonal effects on fire heat release (related to, e.g., fuel moisture content and fuel loads) rather than plant physiological and phenological state have been responsible for seasonal variation in efficacy of prescribed fire control of hardwoods. The increasing application of fire heat measurement equipment should allow progress on this front of prescribed fire research in the coming years.

Increased post-fire survival with green leaves or new leaves sprouted from the crown for upland and sandhill oaks illustrates differences in fire adaptive traits. Upland and sandhill oaks in the understory typically have thicker bark than fleshy-fruited trees and mesic oaks of similar height, which confers greater protection against heat-caused cambial death and girdling (Cavender-Bares et al., 2004; Graves et al., 2014; Hammond et al., 2015). This results in a higher probability of upland and sandhill oaks growing into the mid- and overstory, but those guilds may have little negative impact on fire intensity. We found almost no net effect of upland oaks on FRED, even though litter from both upland and sandhill oaks species has been shown to burn at high intensity (Kane et al., 2008; Varner et al., 2015).

\section{MANAGEMENT CONSIDERATIONS}

The results of this research could be used to predict fire intensity and probability of shrub-form hardwood top-kill based on the spatial arrangement and composition of overstory trees, and a few simple fire weather and fuelbed metrics. To illustrate how models of the effects of the size, species composition, and arrangement of overstory trees could be used to predict FRED and hardwood topkill, we created a contour map of predicted FRED for a dormant-season prescribed fire in a stem-mapped longleaf pine woodland. The Holling type III function with the appropriate parameters for each guild was used to predict FRED for each tree within $20 \mathrm{~m}$ of the center of $1 \mathrm{~m} \times 1 \mathrm{~m}$ grid cells. Total predicted FRED for each cell was the sum of the effects of each tree in the $20 \mathrm{~m}$ radius neighborhood and simple effects of average wiregrass cover and fuel moisture (Figure 4). The resulting map provides predictions of hot and cool spots within the burn area and could be used, for example, to narrow locations to search for crown scorch after fire or to monitor for poor hardwood control. 


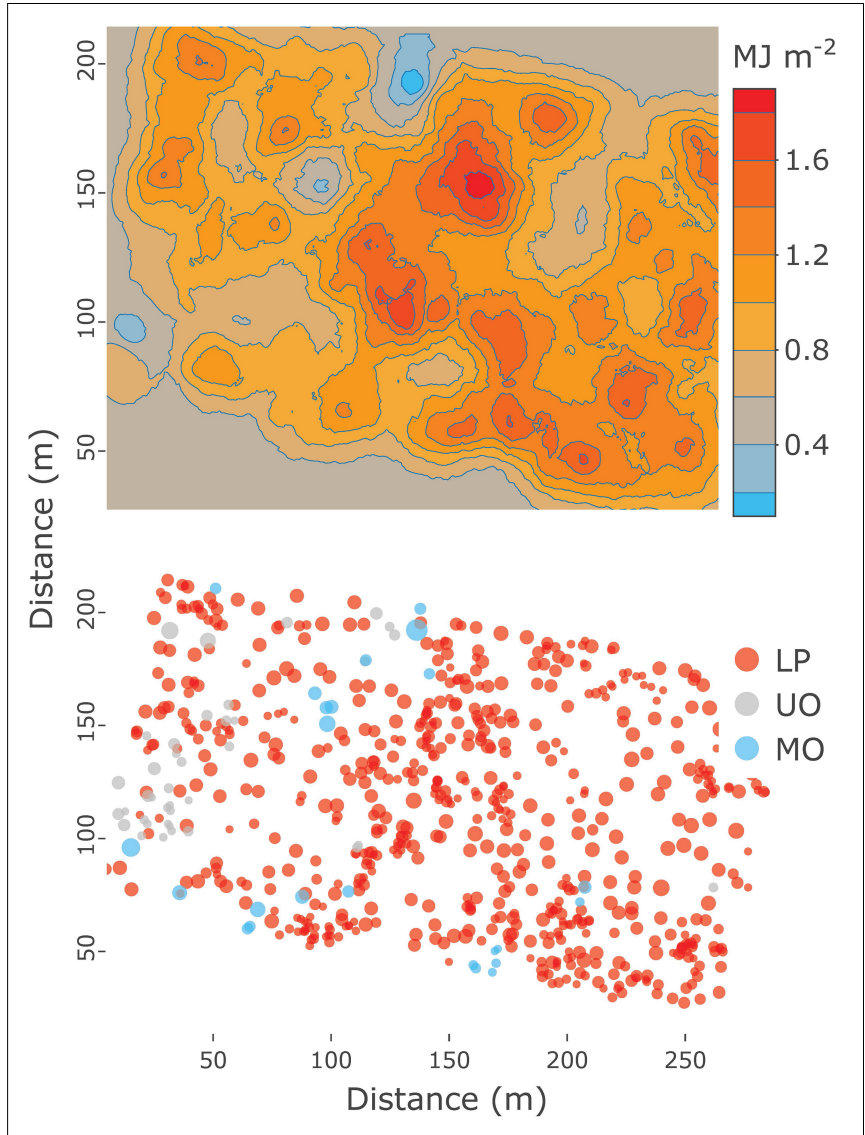

FIGURE 4 | Predicted FRED during dormant-season prescribed fire (top panel) based on $\mathrm{DBH}$, location, and guild of overstory trees (bottom panel). The lowest AICc model was used for predictions of overstory tree effects (see Tables 5, 6). Symbol size reflects DBH. Abbreviations for tree guilds are: LP, longleaf pine; $\mathrm{UO}$, upland oak; and $\mathrm{MO}$, mesic oak.

Longleaf pine tree spatial arrangement can be manipulated for a wide variety of goals, from high density stands for pine straw and timber production to low density woodlands for wildlife (e.g., red-cockaded woodpecker). High-density production forests may warrant little or no prescribed fire, but frequent burning is necessary to maintain the structure, productivity, and biodiversity desirable in more open, natural stands. Maintenance of natural longleaf pine stands with fire is largely concerned with preventing shrub-form hardwoods from growing large and creating a closed canopy. Open canopy structure is accompanied by increased spatial and compositional heterogeneity, which complicates the application of prescribed fire for hardwood control. Natural, uneven-aged longleaf pine stands can be thought of as a matrix of longleaf pine trees with frequent, variously sized gaps. These gaps may be empty or occupied by different tree species; mesic oaks further suppress fire energy in gaps, and upland oaks have little effect on fire energy. Areas of low fire energy are places where hardwood control is more likely to fail, and identification of these areas prior to prescribed burning could yield crucial information that affects burn planning.
Prescribed fires during the dormant-season were of lower average intensity than growing-season fires, but higher fire intensity during the dormant-season is possible. Lower fuel moisture and relative humidity and higher temperatures increase fire intensity, and selecting fire weather during the dormantseason based on these factors can help ensure fire intensity that is high enough for effective control of shrub-form hardwoods. If hardwood control is the primary management goal, prescribed fires should be conducted under conditions conducive to high energy release.

\section{CONCLUSION}

Prescribed fire science has evolved rapidly in recent decades, progressing from field measurements of fire involving, e.g., temperature-sensitive paints, to flame temperatures with thermocouples, to measurements of heat energy. Our research represents an advance in pairing measured and predicted heat energy with neighborhood theory and methods. This procedure allowed us to parse out the contribution of individual trees, and interactions among tree guilds, to radiant energy release. The use of heat release, radiant energy, as a common currency in prescribed fires allows linkage to fire prediction models and mechanistic, heat-transfer models of cambial mortality for fire effects. We found no non-linear surprises in the interaction among different tree guilds in their effects on heat release in a longleaf woodland prescribed fire. Nevertheless, neighborhood models clearly depicted the differing spatial influence of tree guilds on heat release: positive for longleaf pine, neutral for upland oaks, and negative for mesic oaks. Our models of heat release effects on topkill showed the feedbacks to survival of regenerating individuals of these guilds, paving the way for mechanistic modeling of heat transfer and cambial mortality that can enter into an understanding of community dynamics in these managed natural systems.

\section{DATA AVAILABILITY STATEMENT}

The raw data supporting the conclusions of this article will be made available by the authors, without undue reservation.

\section{AUTHOR CONTRIBUTIONS}

JO'B, SB, and AW conceived and planned the experiments and contributed to the interpretation of the results. SB and AW carried out the experiments and analyzed the data. AW took the lead in writing the manuscript. All authors provided critical feedback and helped shape the research, analysis, and manuscript.

\section{FUNDING AND ACKNOWLEDGMENTS}

Anna Rollosson, Emily Laske, and Khalil Carson assisted with field work and data management. Jones Center resource 
managers Scott Smith and Jimmy Atkinson coordinated and supervised experimental fires, and we thank them and fire educator Mark Melvin for sharing their insights into

\section{REFERENCES}

Addington, R. N., Donovan, L. A., Mitchell, R. J., Vose, J. M., Pecot, S. D., Jack, S. B., et al. (2006). Adjustments in hydraulic architecture of Pinus palustris maintain similar stomatal conductance in xeric and mesic habitats. Plant Cell Environ. 29, 535-545. doi: 10.1111/j.1365-3040.2005.01430.x

Babl, E., Alexander, H. D., Siegert, C. M., and Willis, J. L. (2020). Could canopy, bark, and leaf litter traits of encroaching non-oak species influence future flammability of upland oak forests? Forest Ecol. Manag. 458:117731. doi: 10. 1016/j.foreco.2019.117731

Bigelow, S., and Canham, C. (2017). Neighborhood-scale analyses of non-additive species effects on cation concentrations in forest soils. Ecosystems 20, 13511363. doi: 10.1007/s10021-017-0116-1

Bigelow, S. W., and Canham, C. D. (2015). Litterfall as a niche construction process in a northern hardwood forest. Ecosphere 6, 1-14. doi: 10.1007/978-1-46126232-9_1

Bigelow, S. W., and Whelan, A. W. (2019). Longleaf pine proximity effects on air temperatures and hardwood top-kill from prescribed fire. Fire Ecol. $15: 27$.

Blauw, L. G., Wensink, N., Bakker, L., van Logtestijn, R. S. P., Aerts, R., Soudzilovskaia, N. A., et al. (2015). Fuel moisture content enhances nonadditive effects of plant mixtures on flammability and fire behavior. Ecol. Evol. 5, 3830-3841. doi: 10.1002/ece3.1628

Bolker, B. M. (2008). Ecological Models and Data in R. First edition. Princeton, NJ: Princeton University Press.

Bova, A. S., and Dickinson, M. B. (2005). Linking surface-fire behavior, stem heating, and tissue necrosis. Can. J. Forest Res. 35, 814-822. doi: 10.1139/ x05-004

Boyer, W. D. (1993). Season of burn and hardwood development in young longleaf pine stands. In: proceedings of the seventh biennial southern silvicultural research conference. november 17-19; mobile, AL. Gen. Tech. Rep. SO-93. New Orleans, LA: USDA, FS. Southern Forest Exp. Station 511-515.

Burnham, K. P., and Anderson, D. R. (2002). Model Selection and Multimodel Inference: a Practical Information-Theoretic Approach. New York, USA: Springer.

Canham, C. D., Finzi, A. C., Pacala, S. W., and Burbank, D. H. (1994). Causes and consequences of resource heterogeneity in forests: interspecific variation in light transmission by canopy trees. Can. J. Forest Res. 24, 337-349. doi: 10.1139/x94-046

Canham, C. D., LePage, P. T., and Coates, C. D. (2004). A neighborhood analysis of canopy tree competition: crowding vs. shading. Can. J. Forest Res. 34, 778-787. doi: $10.1139 / \mathrm{x} 03-232$

Canham, C. D., and Uriarte, M. (2006). Analysis of neighborhood dynamics of forest ecosystems using likelihood methods and modeling. Ecol. Appl. 16, 62-73. doi: 10.1890/04-0657

Cavender-Bares, A. J., Kitajima, K., and Bazzaz, F. A. (2004). Multiple trait associations in relation to habitat differentiation among 17 Floridian oak species. Ecol. Monogr. 74, 635-662. doi: 10.1890/03-4007

Christensen, R. H. B. (2015). Ordinal - Regression Models for Ordinal Data. $R$ package version 2015. 6-28. Available Online at: https://cran.r-project.org/ package $=$ ordinal $($ accessed October 22, 2020).

de Magalhães, R. M. Q., and Schwilk, D. W. (2012). Leaf traits and litter flammability: evidence for non-additive mixture effects in a temperate forest. J. Ecol. 100, 1153-1163. doi: 10.1111/j.1365-2745.2012.01987.x

Della Rocca, G., Danti, R., Hernando, C., Guijarro, M., and Madrigal, J. (2018). Flammability of two mediterranean mixed forests: Study of the non-additive effect of fuel mixtures in laboratory. Front. Plant Sci. 9:825. doi: 10.3389/fpls. 2018.00825

Dickinson, M. B., Hudak, A. T., Zajkowski, T., Loudermilk, E. L., Schroeder, W., Ellison, L., et al. (2016). Measuring radiant emissions from entire prescribed fires with ground, airborne and satellite sensors-RxCADRE 2012. Int. J. Wildland Fire 25, 48-61. doi: 10.1071/wf15090

Dickinson, M. B., and Kremens, R. L. (2015). RxCADRE 2008, 2011, and 2012: Radiometer data. Fort Collins, CO: Forest Service Research Data Archive. prescribed burning with us. Our research benefited from experimental infrastructure designed by Bob Mitchell (deceased) and established and maintained by Steve Jack.

Ferrari, J. B., and Sugita, S. (1996). A spatially explicit model of leaf litter fall in hemlock-hardwood forests. Can. J. Forest Res. 26, 1905-1913. doi: 10.1139/ x26-215

Fill, J. M., Glitzenstein, J. S., Streng, D. R., Stowe, J., and Mousseau, T. A. (2017). Wiregrass (Aristida beyrichiana) may limit woody plant encroachment in longleaf pine (Pinus palustris) ecosystems. Am. Midland Nat. 177, 153-161. doi: 10.1674/0003-0031-177.1.153

Fill, J. M., Moule, B. M., Varner, J. M., and Mousseau, T. A. (2016). Flammability of the keystone savanna bunchgrass Aristida stricta. Plant Ecol. 217, 331-342. doi: 10.1007/s11258-016-0574-0

Finzi, A. C., and Canham, C. D. (1998). Non-additive effects of litter mixtures on net $\mathrm{N}$ mineralization in a southern new england forest. Forest Ecol. Manag. 105, 129-136. doi: 10.1016/s0378-1127(97)00277-6

Fonda, R. W. (2001). Burning characteristics of needles from eight pine species. Forest Sci. 47, 390-396.

Gagnon, P. R., Passmore, H. A., Platt, W. J., Myers, J. A., Paine, C. E. T., and Harms, K. E. (2010). Does pyrogenicity protect burning plants? Ecology 91, 3481-3486. doi: 10.1890/10-0291.1

Glitzenstein, J. S., Platt, W. J., and Streng, D. R. (1995). Effects of fire regime and habitat on tree dynamics in north Florida longleaf pine savannas. Ecol. Monogr. 65, 441-476. doi: 10.2307/2963498

Goebel, P. C., Palik, B. J., Kirkman, L. K., and West, L. (1997). Field guide: landscape ecosystem types of Ichauway. Newton, GA: Ecological Research Center at Ichauway.

Gormley, A. G., Bell, T. L., and Possell, M. (2020). Non-additive effects of forest litter on flammability. Fire 3:12. doi: 10.3390/fire3020012

Grady, J. M., and Hoffmann, W. A. (2012). Caught in a fire trap: recurring fire creates stable size equilibria in woody resprouters. Ecology 93, 2052-2060. doi: 10.1890/12-0354.1

Graves, S. J., Rifai, S. W., and Putz, F. E. (2014). Outer bark thickness decreases more with height on stems of fire-resistant than fire-sensitive Floridian oaks (Quercus spp.; Fagaceae). Am. J. Bot. 101, 2183-2188. doi: 10.3732/ajb.1400412

Grömping, U. (2006). Relative importance for linear regression in R: The package relaimpo. J. Stat. Software 17, 1-27. doi: 10.3758/s13428-010-0043-y

Hammond, D. H., Varner, J. M., Kush, J. S., and Fan, Z. (2015). Contrasting sapling bark allocation of five southeastern USA hardwood tree species in a fire prone ecosystem. Ecosphere 6:112.

Hendricks, J. J., Wilson, C. A., and Boring, L. R. (2002). Foliar litter position and decomposition in a fire-maintained longleaf pine-wiregrass ecosystem. Can. J. Forest Res. 32, 928-941. doi: 10.1139/x02-020

Hiers, J. K., O’Brien, J. J., Will, R. E., and Mitchell, R. J. (2007). Forest floor depth mediates understory vigor in xeric Pinus palustris ecosystems. Ecol. Appl. 17, 806-814. doi: 10.1890/06-1015

Hodler, T. W., and Schretter, H. A. (1986). Atlas of Georgia. Institute of Community and Area Development. Athens: University of Georgia.

Holland, A. M., Rutledge, B. T., Jack, S. B., and Stober, J. M. (2019). The longleaf pine forest: long-term monitoring and restoration of a management dependent ecosystem. J. Nat. Conserv. 47, 38-50. doi: 10.1016/j.jnc.2018.11.006

Jack, S. B., Mitchell, R. J., and Pecot, S. D. (2006). "Silvicultural alternatives in a longleaf pine/wiregrass woodland in southwest Georgia: understory hardwood response to harvest-created gaps," in Proceedings of the $13^{\text {th }}$ Southern Silvicultural Research Conference, Asheville, USA, 2006. General Technical Report GTR-SRS-92, U.S, ed. K. F. Connor (Asheville, USA: Department of Agriculture, Forest Service, Southern Research Station), 85-89.

Johnson, E. A., and Miyanishi, K. (2001). “Strengthening fire ecology's roots," in Forest Fires: Behavior and Ecological Effects, eds E. A. Johnson and K. Miyanishi (San Diego CA: Academic Press).

Kane, J. M., Varner, J. M., and Hiers, J. K. (2008). The burning characteristics of southeastern oaks: discriminating fire facilitators from fire impeders. Forest Ecol. Manag. 256, 2039-2045. doi: 10.1016/j.foreco.2008.07.039

Kirkman, L. K., and Giencke, L. M. (2017). "Restoring and managing a diverse ground cover," in Ecological Restoration and Management of Longleaf Pine Forests, eds L. K. Kirkman and S. B. Jack (Boca Raton, FL: CRC Press), 207-232. doi: 10.1201/9781315152141-11 
Kirkman, L. K., Giencke, L. M., Taylor, R. S., Boring, L. R., Staudhammer, C. L., and Mitchell, R. J. (2016). Productivity and species richness in longleaf pine woodlands: resource-disturbance influences across an edaphic gradient. Ecology 97, 2259-2271. doi: 10.1002/ecy.1456

Kirkman, L. K., Mitchell, R. J., Helton, R. C., and Drew, M. B. (2001). Productivity and species richness across an environmental gradient in a fire-dependent ecosystem. Am. J. Bot. 88, 2119-2128. doi: 10.2307/3558437

Kremens, R. L., Dickinson, M. B., and Bova, A. S. (2012). Radiant flux density, energy density and fuel consumption in mixed-oak forest surface fires. Int. J. Wildland Fire 21, 722-730. doi: 10.1071/wf10143

Kreye, J. K., Varner, J. M., Hamby, G. W., and Kane, J. M. (2018). Mesophytic litter dampens flammability in fire-excluded pyrophytic oak-hickory woodlands. Ecosphere 9:e02078.

Loudermilk, E. L., Hiers, J. K., and O'Brien, J. J. (2017). “The role of fuels for understanding fire behavior and fire effects," in Ecological Restoration and Managment of Longleaf Pine Forests, eds L. K. Kirkman and S. B. Jack (Boca Raton, FL: CRC Press), 107-122. doi: 10.1201/9781315152141-6

Mcallister, S., and Weise, D. R. (2017). Effects of season on ignition of live wildland fuels using the forced ignition and flame spread test apparatus. Combustion Sci. Technol. 189, 231-247. doi: 10.1080/00102202.2016.1206086

McIntyre, R. K., Jack, S. B., Mitchell, R. J., Kevin Hiers, J., and Neel, W. L. (2008). Multiple value management: the Stoddard-Neel approach to ecological forestry in longleaf pine grasslands, First Edn. Newton, USA: Joseph W. Jones Ecological Research Center.

Mitchell, R. J., Hiers, J. K., O’Brien, J., and Starr, G. (2009). Ecological forestry in the Southeast: understanding the ecology of fuels. J. Forestry 107, 391-397.

Murphy, L. R. (2015). Likelihood: methods for maximum likelihood estimation. $R$ package version 1.7. doi: 10.1139/x06-1000

NCEI. (2010). Monthly normals, Newton 11 SW, GA, USA. Available Online at: https://www.ncdc.noaa.gov/cdo-web/datasets (accessed June 15, 2020).

Nelson, R. M., and Hiers, J. K. (2008). The influence of fuelbed properties on moisture drying rates and timelags of longleaf pine litter. Can. J. Forest Res. 38, 2394-2404. doi: 10.1139/x08-078

O’Brien, J. J., Hiers, J. K., MacCallaham, A., Mitchell, R. J., and Jack, S. B. (2008). Interactions among overstory structure, seedling life-history traits, and fire in frequently burned neotropical pine forests. AMBIO J. Hum. Environ. 37, 542-547. doi: 10.1579/0044-7447-37.7.542

O’Brien, J. J., Loudermilk, E. L., Hiers, J. K., Pokswinski, S. M., Hornsby, B., Hudak, A. T., et al. (2016). Canopy-derived fuels drive patterns of in-fire energy release and understory plant mortality in a longleaf pine (Pinus palustris) sandhill in northwest Florida. USA. Can. J. Remote Sensing 42, 489-500. doi: 10.1080/ 07038992.2016.1199271

Ormeño, E., Céspedes, B. I, Sánchez, A., Velasco-García, A., Moreno, J. M., Fernandez, C., et al. (2009). The relationship between terpenes and flammability of leaf litter. Forest Ecol. Manag. 257, 471-482. doi: 10.1016/j.foreco.2008. 09.019

Ottmar, R. D., and Restaino, J. C. (2014). RxCADRE 2008, 2011, and 2012: Ground fuel measurements from prescribed fires. Fort Collins, CO: Forest Service Research Data Archive.

Pacala, S. W., Canham, C. D., Saponara, J., Silander, J. A. Jr., Kobe, R. K., and Ribbens, E. (1996). Forest models defined by field measurements: estimation, error analysis and dynamics. Ecol. Monogr. 66, 1-43. doi: 10.2307/2963479

Palik, B., Mitchell, R. J., Pecot, S., Battaglia, M., and Pu, M. (2003). Spatial distribution of overstory retention influences resources and growth of longleaf pine seedlings. Ecol. Appl. 13, 674-686. doi: 10.1890/1051-0761(2003)013[0674: sdoori]2.0.co;2

Pecot, S. D., Mitchell, R. J., Palik, B. J., Moser, E. B., and Hiers, J. K. (2007). Competitive responses of seedlings and understory plants in longleaf pine woodlands: separating canopy influences above and below ground. Can. J. Forest Res. 37, 634-648. doi: 10.1139/x06-247

Pederson, N., Varner, J. M., and Palik, B. J. (2008). Canopy disturbance and tree recruitment over two centuries in a managed longleaf pine landscape. Forest Ecol. Manag. 254, 85-95. doi: 10.1016/j.foreco.2007.07.030

Platt, W. J., Ellair, D. P., Huffman, J. M., Potts, S. E., and Beckage, B. (2016). Pyrogenic fuels produced by savanna trees can engineer humid savannas. Ecol. Monogr. 86, 352-372. doi: 10.1002/ecm.1224

Provencher, L., Herring, B. J., Gordon, D. R., Rodgers, H. L., Tanner, G. W., Hardesty, J. L., et al. (2001). Longleaf pine and oak responses to hardwood reduction techniques in fire-suppressed sandhills in northwest florida. Forest Ecol. Manag. 148, 63-77. doi: 10.1016/s0378-1127(00)00525-9

R Core Team. (2020). R: A Language and Environment for Statistical Computing. Available Online at: https://www.r-project.org/ (accessed October 22, 2020).

Reid, A. M., and Robertson, K. M. (2012). Energy content of common fuels in upland pine savannas of the south-eastern US and their application to fire behaviour modelling. Int. J. Wildland Fire 21, 591-595. doi: 10.1071/wf10139

Ribbens, E., Silander, J. A., and Pacala, S. W. (1994). Seedling recruitment in forests: calibrating models to predict patterns of tree seedling dispersion. Ecology 75, 1794-1806. doi: 10.2307/1939638

Robertson, K. M., and Hmielowski, T. L. (2014). Effects of fire frequency and season on resprouting of woody plants in southeastern US pine-grassland communities. Oecologia 174, 765-776. doi: 10.1007/s00442-013-2823-4

Rodgers, H. L., and Provencher, L. (1999). Analysis of longleaf pine sandhill vegetation in northwest florida. Southern Appalachian Bot. Soc. 64, 138-162.

Ruswick, S. K., O’Brien, J. J., and Aubrey, D. P. (2021). Carbon starvation is absent regardless of season of burn in Liquidambar styraciflua L. Forest Ecol. Manag. 479:118588. doi: 10.1016/j.foreco.2020.11 8588

Schwilk, D. W. (2003). Flammability is a niche construction trait: canopy architecture affects fire intensity. Am. Nat. 162, 725-733.

Teske, M. E., and Thistle, H. W. (2004). A library of forest canopy structure for use in interception modeling. Forest Ecol. Manag. 198, 341-350. doi: 10.1016/j. foreco.2004.05.031

Thaxton, J. M., and Platt, W. J. (2006). Small-scale variation alters fire intensity and shrub abundance in a pine savanna. Ecology 87, 1331-1337. doi: 10.1890/00129658(2006)87[1331:sfvafi]2.0.co;2

van Altena, C., van, Logtestijn RS, Cornwell, W. K., and Cornelissen, J. H. (2012). Species composition and fire: non-additive mixture effects on ground fuel flammability. Front. Plant Sci. 3:63. doi: 10.3389/fpls.2012. 00063

Varner, J. M., Kane, J. M., Banwell, E. M., and Kreye, J. K. (2015). Flammability of litter from southeastern trees: a preliminary assessment. In Proceedings of the $17^{\text {th }}$ Biennial Southern Silvicultural Research Conference. e-General Technical Report GTR-SRS-203. Asheville, NC: U.S. Department of Agriculture, Forest Service, Southern Research Station, 183-187.

Varner, J. M., Kane, J. M., Hiers, J. K., Kreye, J. K., and Veldman, J. W. (2016). Suites of fire-adapted traits of oaks in the Southeastern USA: Multiple strategies for persistence. Fire Ecol. 12, 48-64. doi: 10.4996/fireecology.1202048

Whelan, A., Bigelow, S., Nieminen, M., Jack, S., Whelan, A. W., Bigelow, S. W., et al. (2018). Fire season, overstory density and groundcover composition affect understory hardwood sprout demography in longleaf pine woodlands. Forests 9:423. doi: 10.3390/f9070423

Williamson, G. B., and Black, E. M. (1981). High temperature of forest fires under pines as a selective advantage over oaks. Nature 293, 643-644. doi: 10.1038/ $293643 \mathrm{a} 0$

Wooster, M. J., Roberts, G., Perry, G. L. W., and Kaufman, Y. J. (2005). Retrieval of biomass combustion rates and totals from fire radiative power observations: FRP derivation and calibration relationships between biomass consumption and fire radiative energy release. J. Geophys. Res. 110:D24311.

Zhao, W., van Logtestijn, R. S. P., van Hal, J. R., Dong, M., and Cornelissen, J. H. C. (2019). Non-additive effects of leaf and twig mixtures from different tree species on experimental litter-bed flammability. Plant Soil 436, 311-324. doi: $10.1007 /$ s11104-019-03931-3

Conflict of Interest: The authors declare that the research was conducted in the absence of any commercial or financial relationships that could be construed as a potential conflict of interest.

The reviewer AH declared a past co-authorship with one of the authors JO'B to the handling editor.

Copyright (c) 2021 Whelan, Bigelow and O'Brien. This is an open-access article distributed under the terms of the Creative Commons Attribution License (CC BY). The use, distribution or reproduction in other forums is permitted, provided the original author(s) and the copyright owner(s) are credited and that the original publication in this journal is cited, in accordance with accepted academic practice. No use, distribution or reproduction is permitted which does not comply with these terms. 